\title{
Mechanism of Financial Risk Prevention in Local Universities
}

\author{
Dahua Wang \\ Jilin Engineering Normal University Changchun, Jilin 130052 \\ 894161521@qq.com
}

\begin{abstract}
Keywords: Universities; Financial Risks; Prevention; Mechanism
\end{abstract}
\begin{abstract}
Some practical measures were proposed to prevent financial risks in local universities on the basis of an analysis of their forms and possible causes in view of actual performance of these schools in the field.

To meet the demands over high quality talents of social and economic development, 198 local universities were set up from 1999 to 2005 upon the approval by the Ministry of Education of China, resulting in subsequent prosperity of local higher education and local economic and social development. On the one hand, these universities were founded to serve local economic development; on the other hand, some of them are either out of the combination of several schools or upgraded from 2 or 3-year colleges to 4-year universities. Since the purpose of such a practice is to assist local economic growth, a majority of the expenses of these universities comes from local financial funds. However, it has to be admitted that financial investment from local government is only about $20 \%$ of total expenditure for routine operation, and the proportion is even lower, especially in some underdeveloped regions. Additionally, some of the universities based on the combination of several schools or upgraded from junior colleges may be challenged by more serious economic difficulties, e.g. a series of jobs like campus expansion, equipment procurement and high-level teachers introduction for improvement of teaching quality, etc. require more financial support, which as a result leads to more and more severe conflicts between investment and demands in local universities. To solve the problem, local universities tend to apply for bank loans to raise educational funds. Although bank loans can resolve capital problems in a short term, due principal plus interest in high amounts also brings forth huge pressure and financial risks to these universities. Besides, such risks will become even more serious owing to the defects in their administrative mechanism. Therefore, how to avoid financial risks successfully has become an important factor in the healthy sustainable development of local universities.
\end{abstract}

\section{Possible Causes of Financial Risks in Local Universities}

Financial risk, a concept originated from company financial management, is the uncertainty that of a company's financial conditions owing to the uncertainty of its repayment of a due loan with monetary capital in daily operation. For local universities, its financial risks arise from the negative effects upon their financial conditions of the financial uncertainties as a result of both external and internal factors in various financial business. In an extreme situation, a local university may even fail to run its financial business if it can not repay due loans, which in turn imposes a threat upon the existence of the university, let alone development. Generally speaking, financial risks for a local university, whether they are universal ones or peculiar to itself, are often attributed to the factors listed as below:

Pressure from university assessment of the state. For some upgraded universities or those as the combination of several junior colleges, they are in need of investment in large amounts for equipment procurement, facility expansion and faculty employment to meet the requirements in the teaching assessment plan for universities by the Ministry of Education. As a result of the increasing economic pressure, they are exposed to more serious financial risks. In addition, it has to be pointed out that most local universities depend on monthly financial transfer from local governments and its own tuition fees for they have very few other financial sources. However, the former is mainly used to cover daily expenditure and there is seldom any balance, while the amount of the latter as a financial support is specified not by a university but by the government department at a higher level. 
Besides, a majority of university's financial funds paid centrally by the Treasury is treated through zero-balance accounts and any income of tuition fees shall have to be handed in some time before being returned to the universities. All of these financial uncertainties have led to great financial risks for a university's expenditure. Furthermore, serious delay payment of tuition fees by some students, including those from poverty-stricken families who fail to pay the tuition or repay student loans, is also a factor which helps raise the financial risks.

Expansion of local universities. Recent years have witnessed an obvious rise in the enrollments of local universities. Since present conditions can not meet the demands of increasing students, they have to invest large amounts of money in campus infrastructure. However, insufficient financial transfer from local governments, esp. in some underdeveloped areas, though increasing year by year, restrained expansion and construction of local universities. They have to depend more on bank loans in large amounts at a high interest rate, which bring forward greater financial pressure and risks to them. For example, some university has to repay interests as much as several ten-million yuan every year. Moreover, some local universities are not much aware of the potential risks from bank loan for they believe that government will not sit by if they can not repay the loan. Such a misconception accounts for some local universities' lack of alert and awareness of risk prevention.

\section{Preventive Measures against Financial Risks}

The financial risks said above are an inevitable result of local universities' operation on borrowings in the context of higher education expansion. These risks can be found in various fields of financial management and caused by different factors. To eliminate or at least reduce these risks, the school authority of a university has to update their financial knowledge on the one hand; on the other hand, local government and banks should offer greater financial supports to local higher education. Specifically, the following measures should be taken as preventive practice:

To Formulate a Scientific Risk Response Plan. It is of great importance for local universities in China to reinforce their financial risk management as they are developing themselves in a market full of uncertainties. The school authority of a university has to develop a correct understanding about the financial risks which may occur in fund raising, educational investment and school operation involved in school management. Firstly, university leaders have to pay more attention to the prevention of financial risks and remain alert to any potential risk, esp., the conflicts between the capital needed for school expansion and the school's economic capabilities to repay any loan before fund raising or investment. Secondly, a local university should establish a perfect warning system for financial risks and formulate scientific risk control measures based on its actual conditions so as to intervene any financial problem in time through accurate financial calculation.

To Open up more Channels of Fund Raising. An effective measure to avoid financial risks is to open up more fund sources besides banks. On the one hand, a local university should try to obtain greater financial support from relevant governmental departments and acquire more economic gains from school-run enterprises in compliance with relevant favorable national policies. On the other hand, local universities may avoid financial risks from bank loans by way of cooperative complementation of human resources and other advantages between universities, enterprises and scientific research institutes. In this way, local universities can obtain financial supports from the cooperators to lower their financial risks. At the same time, the school authority should try every rational and effective means, e.g. honesty education for students, to collect unpaid tuition fees while providing more scholarships for the students.

\section{Conclusion}

It is a long-term and systematic process for local universities to establish and perfect a financial risk prevention mechanism, and factors of many other fields should be taken into consideration during its optimization. A local university should be active in the discovery and resolution of problems to lower the financial risks and improve its capabilities of prevention for the healthy sustainable development. 


\section{References}

[1] Liu Chunhui. Considerations on connotation-oriented transition of financial management in local universities in the new situation[J]. China Chief Financial Officer, 2017(01): 182-83.

[2] Fan Yi. An analysis of university financial management system - with a local university as an example[J]. Accountant, 2016 (01) 73-74.

[3] Tang Jing. Problems of financial risk control of local universities and relevant solutions[J]. Economic \& Trade, 2016 (16): 204.

[4] Li Zhengguang. An analysis of unique construction path for financial management specialty in local universities[J]. China Collective Economy, 2016 (15): 154-155.

[5] Li Jinxin. An analysis and study of problems of financial budget management in local universities[J]. Money China, 2015 (23): 294.

[6] Tan Jingyu, Shen Jingqiu. Secondary financial management operational mechanism in local universities[J]. Journal of Changchun Normal University, 2015 (12): 185-188.

[7] Zhang Yingying. Early warning system of university financial risks[J]. Science, Economy and Market, 2015 (12): 179-180.

[8] Xiao Yan. Construction and improvement of financial risk preventive mechanism in universities[J]. Enterprise Reform and Management, 2014(12): 225-225.

[9] Li Hongxia. A study on financial management system in local universities and improvement. Jounal of Wuzhou University, 2014 (02): 24-27.

[10] Wang Haixia, He Fei. Financial risk prevention in universities and internal control mechanism[J]. Journal of Liaoning Educational Administration Institute, 2006, 23 (1): 111-113. 